Dalibor VIDERŠČAK, mag. ing. mech. ${ }^{1}$

(Corresponding author)

E-mail: dalibor.viderscak@fsb.hr

Zdravko SCHAUPERL, Ph.D., Prof. ${ }^{1}$

E-mail: zdravko.schauperl@fsb.hr

Krunoslav ORMUŽ, M.Sc. ${ }^{1}$

E-mail: krunoslav.ormuz@fsb.hr

Sanja ŠOLIĆ, Ph.D., Assoc. Prof. ${ }^{2}$

E-mail:ssolic@unin.hr

Mladen NIKŠIĆ, Ph.D., Assoc. Prof. ${ }^{3}$

E-mail: mladen.niksic@fpz.unizg.hr

Diana MILČIĆ, Ph.D., Prof. ${ }^{4}$

E-mail: diana.milcic@grf.hr

Pavao ORMUŽ, mag. ing. mech. ${ }^{1}$

E-mail: pavao.ormuz@gmail.com

${ }^{1}$ Faculty of Mechanical Engineering and Naval

Architecture, University of Zagreb

Ivana Lučića 5, 10000 Zagreb, Croatia

${ }^{2}$ University North, Department of Mechanical Engineering

J. Križanića 31b, 42000 Varaždin, Croatia

${ }^{3}$ Faculty of Transport and Traffic Sciences

University of Zagreb

Vukelićeva 4, 10000 Zagreb, Croatia

${ }^{4}$ Faculty of Graphic Arts, University of Zagreb

Getaldićeva 2, 10000 Zagreb, Croatia
Safety and Security in Traffic Original Scientific Paper Submitted: 24 Mar. 2021 Accepted: 17 Aug. 2021

\title{
INFLUENCE OF BRAKE PAD PROPERTIES TO BRAKING CHARACTERISTICS
}

\begin{abstract}
In this research, field and laboratory testing of three commercially available brake pads with the lowest, middle, and highest price were performed. Complex field testing, where brake pads were tested in real extreme conditions on a loaded van vehicle and laboratory tests were performed. The field testing intended to investigate the temperatures that occur during the braking process and to determine the stopping distance, deceleration, and stopping time separately on the type of brake pads. Laboratory tests included the determination of the friction coefficient according to ASTM G77, the structure of brake pad surfaces before and after the testing, and quantitative chemical analysis of brake pads. The aim of this study was to determine the influence of brake pad temperature on braking time depending on their purchase prices. The obtained results show a significant difference between the temperature, friction coefficient, chemical composition, and braking time of the brake pads and their price.
\end{abstract}

\section{KEYWORDS}

automobile; brake pads; stopping distance; deceleration; friction coefficient; composition; field testing.

\section{INTRODUCTION}

Throughout history, at the beginning of the automotive industry, not much attention was paid to brakes and braking systems, for which there was a justified reason. The first cars had engines with low power and developed low speeds, so the brakes were not such an important part of the car. As the automotive industry developed, increasing power and speed showed the importance and need for a quality braking system because the vehicle could not be easily stopped anymore.

Automotive braking systems convert the kinetic energy of a vehicle into friction-generated thermal energy between the brake pad and the brake disc. Hydraulically actuated disc brakes are most commonly used where the piston presses the brake pads to the disc causing friction and heating, but also small amounts of brake lining material being transferred to the disc due to friction, which slows down the car [1-3]. About $90 \%$ of the energy is taken over by the brake disc, which then needs to be handed over to the environment. In extreme conditions, the disc can reach temperatures up to $650^{\circ} \mathrm{C}$. Deformation of the 
brake discs occurs due to the heating and the thermal expansion which changes the shape of the friction surface of the disc from flat to conical. As a result, the contact between the brake pad and the disc is not achieved over the entire surface but through multiple points, leading to non-uniform wear of the brake pad, and thus to the appearance of unwanted noise [4-6].

Heavy loads that occur due to the changes in temperature of the material can cause the appearance of cracks on the friction surface on the brake disc. The appearance of the surface cracks affects the strength of the brake disc surface and, depending on the size and the load, can cause the initiation of brake material failure. Today's brake discs are made of pearlite grey cast iron with the addition of chromium $(\mathrm{Cr})$ and molybdenum $(\mathrm{Mo})$ to increase wear resistance and reduce the risk of cracks at high temperatures. The addition of carbon (C) increases thermal conductivity and heat transfer rate $[7,8]$.

In hydraulically operated disc brakes, the brake pad with the disc forms a friction pair that serves to convert the clamping force (compression) into braking torque and is used in pairs (one on each side of the disc, Figure 1). The wear of brake pads depends on the type and weight of the vehicle, the speed of movement before braking, and on the properties of brake pad and brake disc materials. Brake pads are regularly changed (depending on exploitation conditions) to meet the required conditions for the normal functioning of the brake system and therefore the brake pads are equipped with a wear warning system [9-11]. There are several types of brake pads (depending on the purpose), soft and aggressive that are used for racing purposes and harder and more durable ones for use on classic commercial vehicles. Automotive manufacturers prescribe a specific

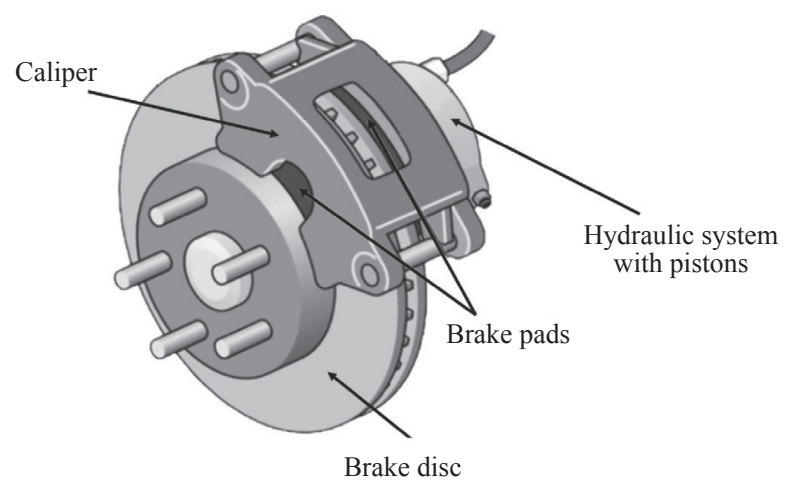

Figure 1-Hydraulic disc braking system [11] type of brake pads for vehicles, but in exceptional cases, other types may be installed for the increased braking performance $[1,2-5]$.

Brake pads are made of composite materials. The main components of the brake pads are reinforcements, binders, fillers, abrasives, and additives (lubricants). It is important to note that certain components perform multiple functions $[13,14]$.

Reinforcers (usually fiber reinforcements) are the main component in terms of mechanical properties, wear resistance, and thermal stability. The most used friction materials are mineral fibres, metal, polymer, glass, aramid, and aluminium-oxide [15].

Binder connects all components to a compact thermostable structural matrix. Thermo-reactive polymers are mainly used; phenolic, polyamide and ester resins, and polyurethane rubber. Their primary function is to ensure the mechanical strength and integrity of the brake during production and exploitation under extreme operating conditions. An additional function of binders is to dampen vibrations and improve comfort during braking. Also, the binder should have high thermal stability and resistance to oxidation at high temperatures $[13,14]$.

Fillers are used for the improvement of thermal conductivity, porosity, and wear resistance, for noise reduction and to improve workability. Fillers are cheaper materials that are used to reduce the cost of the brake pad without compromising properties. The most common fillers used are calcium carbonate $\left(\mathrm{CaCO}_{3}\right)$ and barium sulphate $\left(\mathrm{BaSO}_{4}\right)$ [16].

Additives are special materials used for adjustment and optimisation of the friction properties and control of the wear behaviour of brake pads. They can be classified into two groups: lubricants and abrasives. Lubricants are used to reduce the wear of brake pad materials. An excellent lubricant to use is graphite which decreases the wear rate of the brake because it reduces direct contact between the brake pad surface and the disc. Abrasives are mainly metal oxides in the form of powders that are used to create a high and stable layer between the brake pad and the disc during the braking process, and increase the friction coefficient and wear resistance of the friction material. Metal sulphides, magnesium oxides, zirconium oxides, aluminium oxides, and chromium oxides are the most commonly used [16].

Brake pad materials belong to the most complex composite materials produced because they contain three different types of materials: metals, ceramics, and polymers. The large chemical and physical di- 
versity of the components makes it difficult to find the right ratio and composition of components. In general, friction materials must withstand high load conditions and temperatures, but they must also meet the durability, comfort, availability, and safety requirements [6].

The composition of the brake pad should be optimised to meet the constant friction coefficient for different working conditions (pressure, speed of slippage, and temperature) [6].

\section{BRAKING PROCESS}

During the braking process, various exploitation mechanisms occur that cause high temperatures and wear of brake pads and disc materials. Wear mechanisms of adhesion and abrasion occur due to the high contact load of the disc and brake pad. The surface of the brake pad has a friction material layer, which is the basis of the braking system, and it is defined by two contact surfaces: primary and secondary. When braking, the brake pad touches the disc with the hardest particles of the surface friction material in contact with the disc, forming the micro-grooves on the disc with the formation of abrasive particles $[17,18]$.

The combination of temperature, pressure, and tangential force groups abrasive particles, compresses them, and accumulates them along the disc surface. Particle accumulations are of heterogeneous structures and every time the disc and the friction material are in contact, fragments of removed abrasive particles are released into the atmosphere in the form of dust. The particle size is larger than $100 \mu \mathrm{m}$ with much higher hardness than the hardness of the disc $[19,20]$.

Wear of the pads occurs due to loss of support for fibres that are separated due to irregularities or impurities of the disc. In the braking system, more intense wear will occur with braking at high speeds

Table 1 - Brake system properties depending on braking intensity [1]

\begin{tabular}{||c|c|c|c||}
\hline $\begin{array}{c}\text { Brake } \\
\text { intensity }\end{array}$ & $\begin{array}{c}\text { Pedal } \\
\text { pressure force } \\
{\left[\mathrm{N} / \mathrm{mm}^{2}\right]}\end{array}$ & $\begin{array}{c}\text { Deceleration } \\
{\left[\mathrm{m} / \mathrm{s}^{2}\right]}\end{array}$ & $\begin{array}{c}\text { Temperature } \\
\text { on contact } \\
{\left[{ }^{\circ} \mathrm{C}\right]}\end{array}$ \\
\hline \hline $\begin{array}{c}\text { Normal } \\
\text { braking }\end{array}$ & $0.2-1.0$ & $<2$ & $<300$ \\
\hline $\begin{array}{c}\text { Intense } \\
\text { braking }\end{array}$ & $1.1-4.0$ & $>5$ & $>300$ \\
\hline
\end{tabular}

(Table 1) due to the development of heat in the material, which reduces the friction coefficient, which in turn affects the efficiency of the entire system [1].

High temperatures affect the friction coefficient between the brake pads and discs. At normal operating temperatures, which occur due to vehicle deceleration, the impact is insignificant. When excessively straining the parts of the braking system with instant pressure to the brake pedal in a sudden situation, the friction coefficient drops significantly, and for braking to be effective, it is necessary to press the brake pedal more strongly.

Problems occur when the brake disc temperature increases and causes a change in the friction coefficient between the brake disc and the brake pad, and a change in the temperature of the brake fluid. This is termed as 'fade', i.e., a decrease in the action of the brakes due to an excessive increase in the temperature of the brake disc and brake lining [20,21].

The assessment of the thermal, mechanical, and physical properties of brake pads are of great importance because they provide insight into the behaviour of the overall correlation between efficiency, safety, and wear of brake pads as well as the whole braking system.

There is a large number of brake pads on the market for the same type of vehicle. In this study, the properties of brake pads with large differences in price for the same type of vehicle were tested and compared. Properties tested in this research are of great importance for the efficiency of the braking system and for the safety of the drivers and the passengers in the vehicles [18-20].

\section{EXPERIMENTAL WORK}

\subsection{Devices and methods for determining braking pads properties}

To determine the difference in the stopping distance and the temperature that develops on the front brake pads, tests were conducted on the test track of Centre for Vehicles of Croatia $(\mathrm{CVH})$, Velika Gorica. The test track is an asphalted service runway with a length of $2200 \mathrm{~m}$. Three brake pads (and three sets of the disc) were selected to determine and compare the properties. The selected brake pads are divided into three groups of samples: the first sample represents the braking pads with the highest market price, the second sample braking pads has 
the lowest price, while the third sample represents the braking pad with the median price purchased in free sale.

The vehicle used for test purposes was the VW Transporter T5 2.0 TDI 2012 (closed, wagon, L1H1) van (Figure 2). The van without additional load has a mass of $1794 \mathrm{~kg}$, while its maximum permissible mass is $2800 \mathrm{~kg}$. The car is $4892 \mathrm{~mm}$ long, $1904 \mathrm{~mm}$ wide, and $1970 \mathrm{~mm}$ high. The wheelbase is $3000 \mathrm{~mm}$. The van is equipped with two-circuit hydraulic disc brakes on all wheels with a vacuum braking force enhancer. On the front wheels, there are ventilated discs with a diameter $\Phi 308 \mathrm{~mm}$, and the brake jaws are stationary with 4 pistons. At the time of the van test, Continental Van Eco's summer profile pneumatics with a dimension of 205/65 R16 $\mathrm{C}$ were installed on all wheels.

To ensure for the initial test conditions to always be the same, and to eliminate the impact of the brake discs used before each stopway and tempera- ture test, new discs and brake pads were placed on the vehicle and 100 kilometres drive was performed before each testing for the adaptation purpose.

The van was loaded with $9.8 \mathrm{kN}$ of additional cargo (sand in bags on the pallet) and it leaned against the partition between the passenger and cargo compartments. Each time before testing on the test runway, the car was weighed at the technical inspection station, and the brake system on the brake test rollers was checked/tested. Before each test, weighing the car was carried out to confirm the weight of the car loads of the front and rear axles.

Weighing the loaded car $(9.8 \mathrm{kN}$ of cargo (Figure 3) and the weight of the driver and co-driver) established the load on the front and rear characteristics. The total weight of the car was $30.3 \mathrm{kN}$ on average. The average load of the front axle during the test was $16.4 \mathrm{kN}$ (individually the front left wheel was $8.2 \mathrm{kN}$ and the front right wheel was $8.2 \mathrm{kN}$ ). The average load of the rear axle was $13.8 \mathrm{kN}$ (individually, the rear left wheel was $7.1 \mathrm{kN}$ and the rear
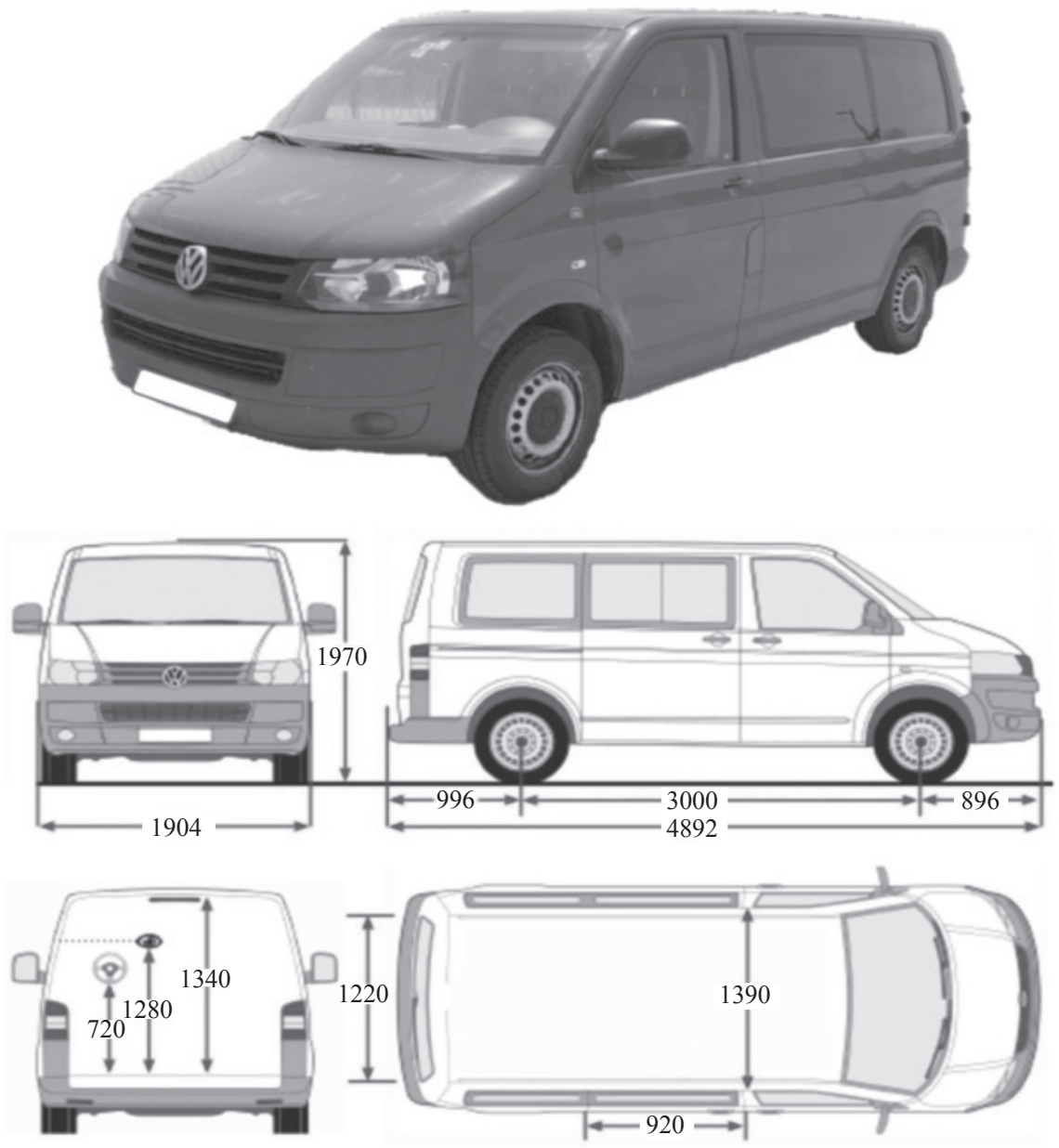

Figure 2 - VW Transporter T5 with dimensions 


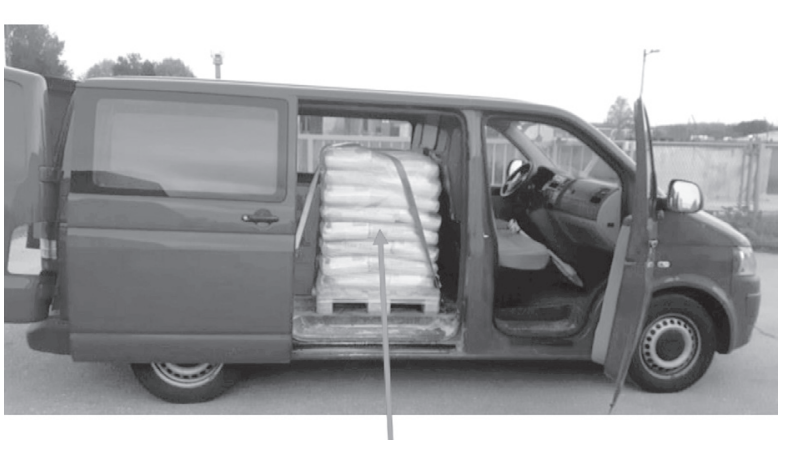

Additional load (cargo) $9.8 \mathrm{kN}$

Figure 3-VW Transporter T5 loaded with additional cargo

right wheel was $6.7 \mathrm{kN}$ ). The maximum difference in measurements of up to $0.1 \mathrm{kN}$ was established, which is considered given the total mass, to be a negligible deviation.

The test was carried out in such a way that the van accelerated to $100 \mathrm{~km} / \mathrm{h}(27.7 \mathrm{~m} / \mathrm{s})$ and then stopped the car with intensive braking. The co-driver would exit the car and use a pyrometer to measure the current disc temperature of the front right and left wheels as close as possible to the brake jaws. The passenger would then re-enter the car, the car would accelerate again and reach speeds of 100 $\mathrm{km} / \mathrm{h}$ and repeat the braking. With such a testing regime, the intention was to reduce the time of the wheel temperature to a minimum so that the brakes would not have time to cool down.

Slowing and stopping distances were measured with Race Logic Drift-Box (10 Hz, GPS). The device contains displacement sensors that allow you to measure the vehicle's " $G$ " force, speed, deceleration, acceleration, and stopping distance. All parameters are saved to the SD memory card, and the custom Race Logic software reads the data displayed as diagrams $(n=9)$.
Measuring the friction coefficient was carried out by the block on ring method

(Figure 4) according to ASTM G77 $(n=5)$. The temperatures of the brake pads and discs were measured by a portable pyrometer $(n=3)$, Voltcraft IR 650-16D IR-THERMOMETER (Temperature range $-40^{\circ} \mathrm{C}$ to $+650^{\circ} \mathrm{C}$, Accuracy $\pm 2^{\circ} \mathrm{C}$ ). The structure of brake pad surfaces before and after the testing was analysed using the Olympus GX51F-5 light microscope. Quantitative chemical analysis of brake pads was determined on the XRF device Innov-X Systems, Inc., USA, model DS 2000-C (XRF cannot determine carbon content $\mathrm{C}$ ).

\subsection{Brake pads properties}

Three types of braking pads were used for testing in a VW Transporter T5 2.0 TDI 2012 van (M1/ N1). Brake pads were purchased from a large retailer of "non-original parts" for cars in Zagreb, where different manufacturers and price ranges were selected.

The most expensive brake pads of the world-renowned manufacturer SAMPLE 1, which produces parts of braking systems for the first installation (the price of the front wheelset is 78 EUR), brake pads of unknown manufacturer SAMPLE 2 (price 39 EUR), and brake pads of the famous manufacturer SAMPLE 3 (price 43 EUR).

All brake pads (Figure 5) had an E-mark printed on the packaging and can be distributed to the market of spare parts intended for public road transport in Europe. Thus, SAMPLE 1 has the code E1, which means that the plate is approved in Germany, SAMPLE 2 is E20 - Poland, and SAMPLE 3 has the code E4 - Netherlands. The main properties for each brake pad provided by manufacturers are presented in Table 2.

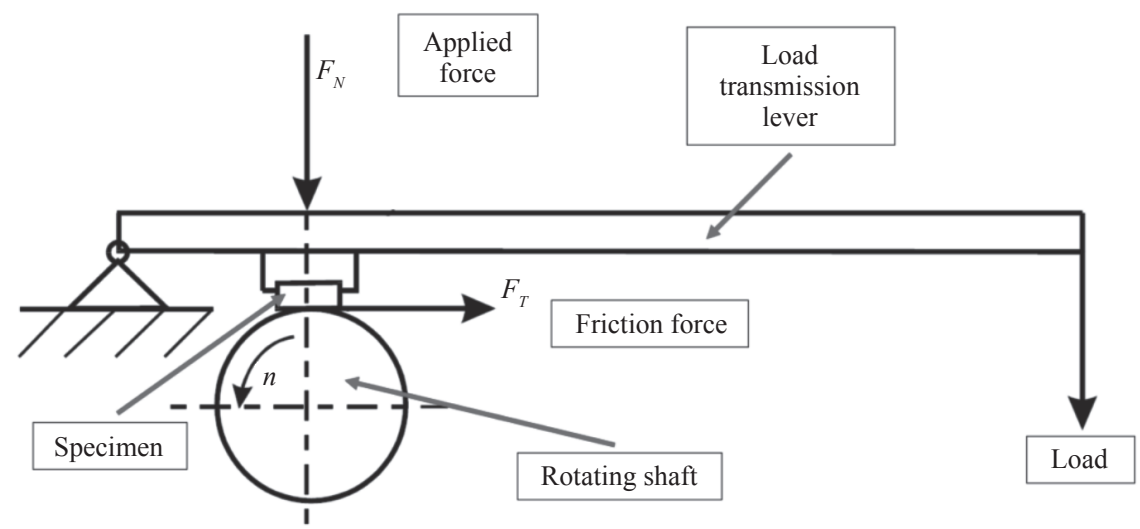

Figure 4 - Block on ring method - ASTM G77 [22] 


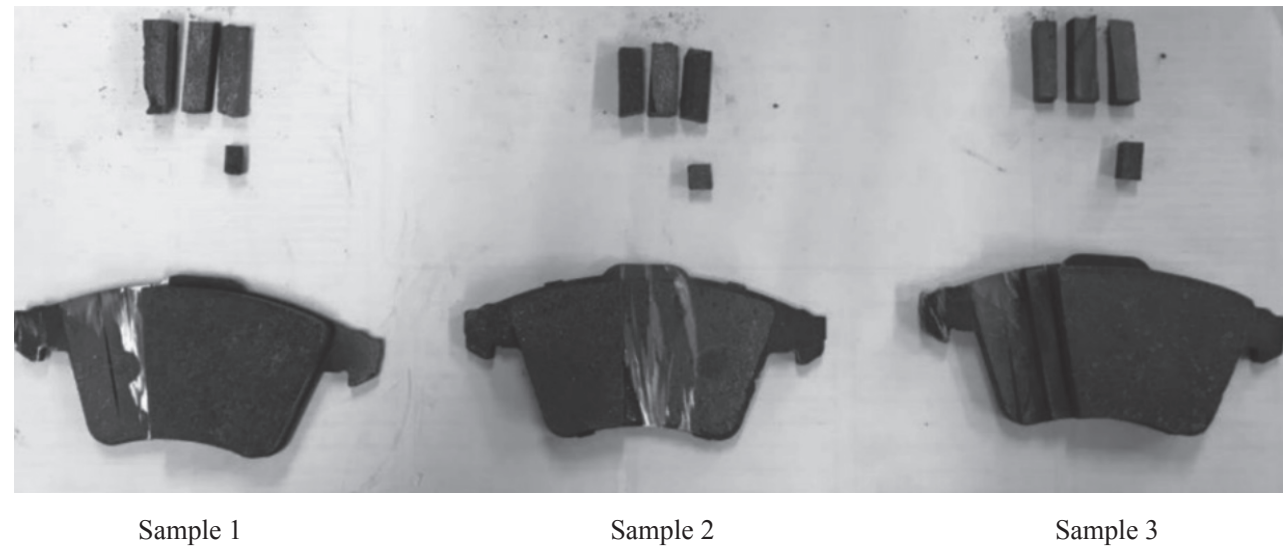

Figure 5 - Brake pads samples

Table 2 - The main properties of the tested brake pads [1]

\begin{tabular}{||c|c|c|c|c|c|c||}
\hline Brake pad & $\begin{array}{c}\text { Density } \\
{\left[\mathrm{g} / \mathrm{cm}^{3}\right]}\end{array}$ & $\begin{array}{c}\text { Compressibility } \\
{[\%]}\end{array}$ & $\begin{array}{c}\text { Minimum shear } \\
\text { force }[\mathrm{MPa}]\end{array}$ & $\begin{array}{c}\text { Maximum press } \\
\text { force }\left[\mathrm{N} / \mathrm{cm}^{2}\right]\end{array}$ & $\begin{array}{c}\text { Maximum } \\
\text { continuous holding } \\
\text { temperature }\left[{ }^{\circ} \mathrm{C}\right]\end{array}$ & $\begin{array}{c}\text { Maximum } \\
\text { temperature } \\
{\left[{ }^{\circ} \mathrm{C}\right]}\end{array}$ \\
\hline \hline Sample 1 & 3.19 & 1.0 & 250 & 800 & 350 & 800 \\
\hline Sample 2 & 3.05 & 1.3 & 250 & 800 & 350 & 800 \\
\hline Sample 3 & 3.08 & 1.8 & 250 & 800 & 350 & 800 \\
\hline
\end{tabular}

\section{RESULTS AND DISCUSSION}

For each of the 3 samples, speed-time diagrams were recorded and they show the dependence of the test time, i.e., the stopping time and the vehicle speed expressed in kilometres per hour (sudden braking from a driving speed of $100 \mathrm{~km} / \mathrm{h}$ was tested). Diagrams in Figure 6 show each separate acceleration and braking/stopping of the vehicle for all three samples. From each diagram, nine relevant braking instances/brake applications are selected for each sample, and these results are presented in Table 3.

For Sample 1, it can be noted that the temperature and braking path increase with each braking. In this case, after nine conducted breaking tests the disc failed to heat up more, and the temperature remained relatively low (compared to other plates). Although the deceleration was reduced by heating, there was no dangerously low deceleration. Afterwards, the test was repeated at the driving speed of $130 \mathrm{~km} / \mathrm{h}$, stopping with intensive braking of the car. The intention was to check if it was possible to overheat the brake and get the fading. However, the brake pads of Sample 1 failed to overheat again. At the end of the test, the disc temperature of $470^{\circ} \mathrm{C}$ was measured, but the brakes were still running with no traces of fading or flame.
From the test results for Sample 2, it can be noted that the temperature and stopping path increase with each braking. During the ninth test, a temperature of $458^{\circ} \mathrm{C}$ was measured but also the flames were developing on the right wheel in the area of the braking jaw (disc and brake pad). The car was started and accelerated for the air cooling of the disc and extinguishing the flames on the brake pad. After that, the brake pad ran out of friction features and the test was interrupted.

The data for Sample 3 also show that the temperature of the brake linings increases as expected by braking, and thus the stopping distance also increases. On this sample, nine measurements were performed as well, but no inflammation (flame) was observed in the jaw area and there was no need to interrupt the test. The deceleration at the end of the test was significantly reduced, and the driver's impression was that, after the test, the brakes were significantly less effective.

Figure 7 shows the surface structure of the brake pads before (a) and after the test (b).

The dark surface in Figure 7 represents a matrix (resin) used as a binder for the components of the friction layer and reinforcing fibres are marked by red squares. Large white clusters (yellow arrows in Figure 7) correspond to the metal particles used as a filler to reduce braking noise $[1,2,6,8,12]$. Blue arrows on the surfaces after the test indicate worn 
Viderščak D, et al. Influence of Brake Pad Properties to Braking Characteristics

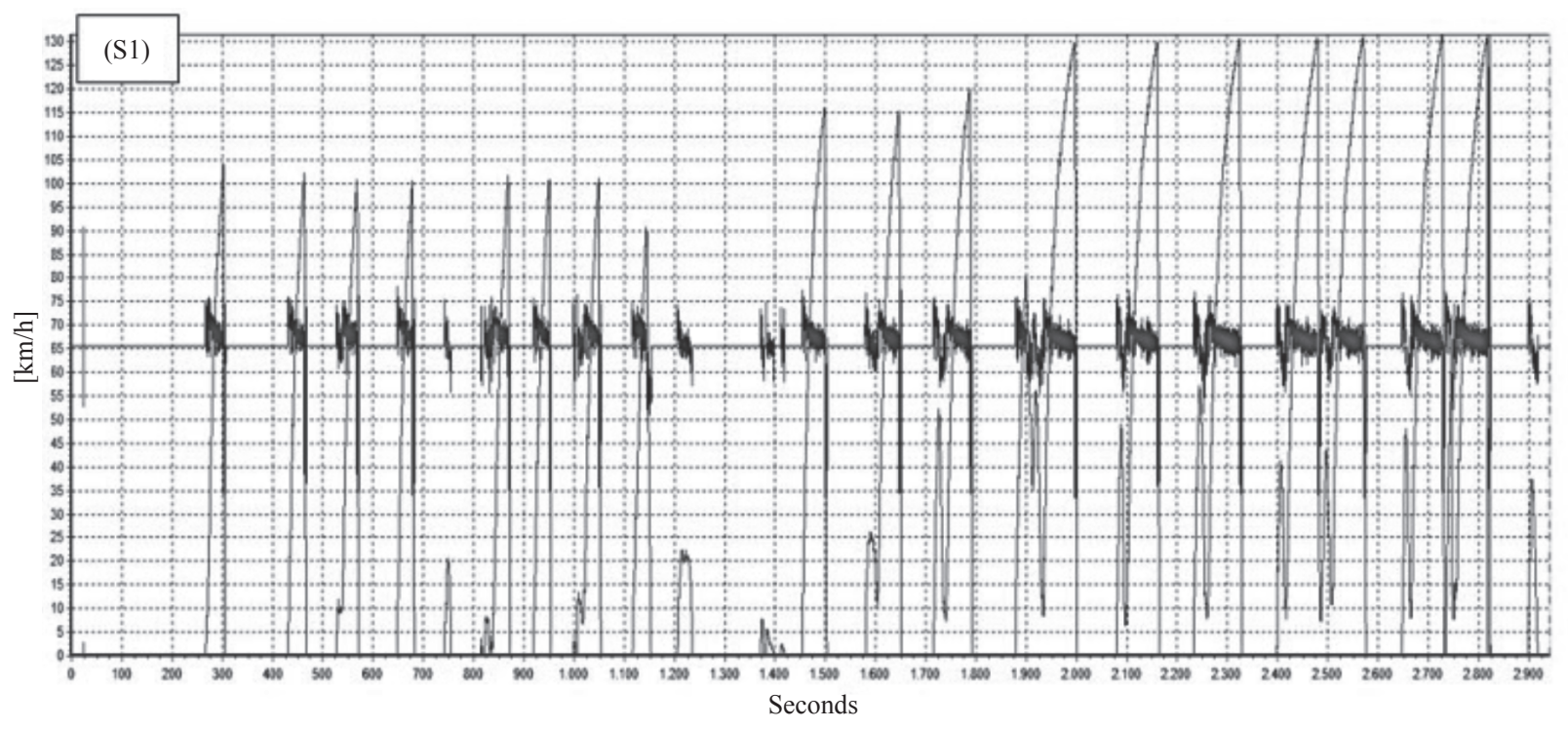

a) Sample 1 (S1)
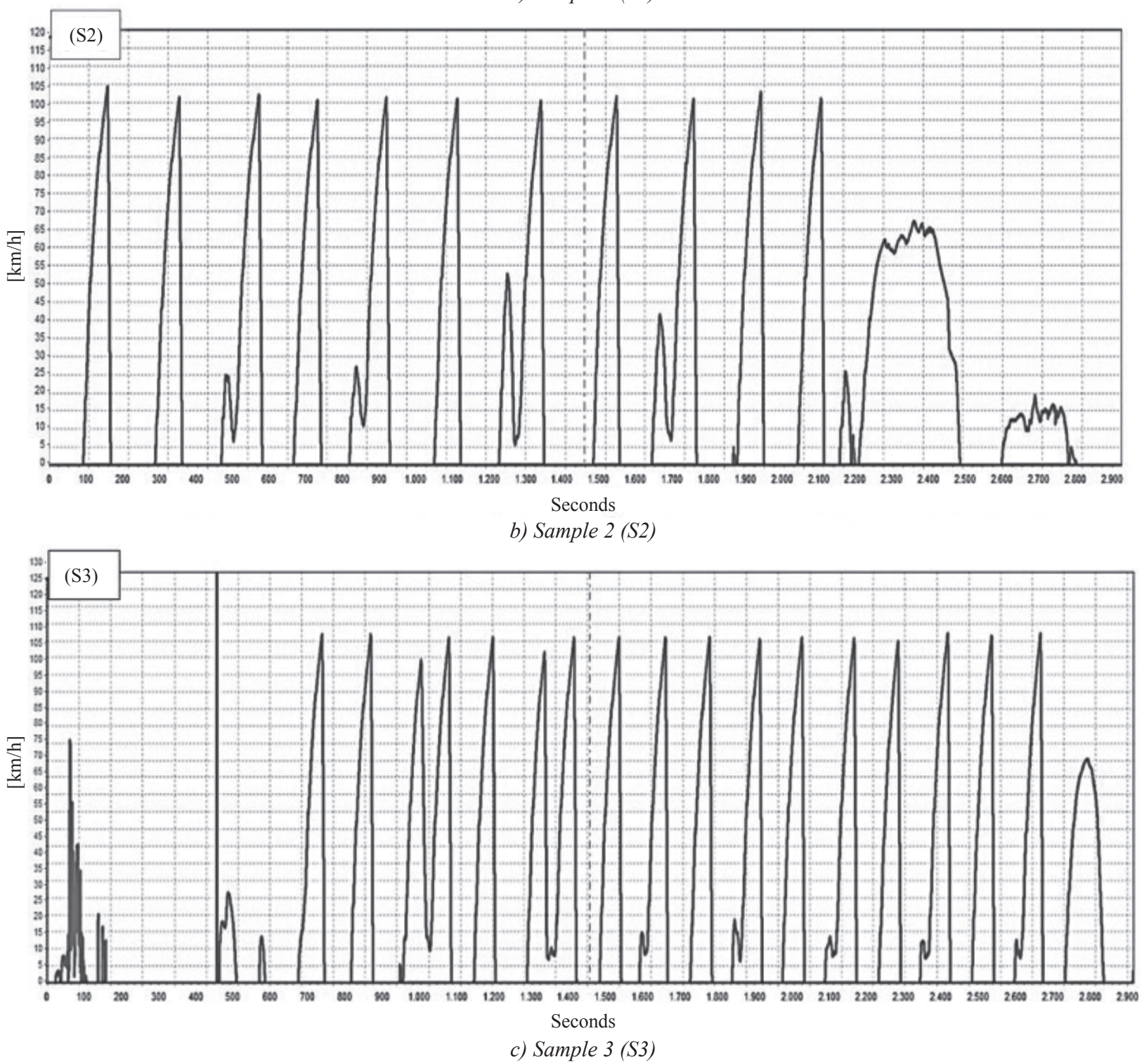

Figure 6-Speed-deceleration diagrams 
Viderščak D, et al. Influence of Brake Pad Properties to Braking Characteristics

Table 3 - Test results for samples S1, S2, and S3

\begin{tabular}{|c|c|c|c|c|c|c|}
\hline Sample & Starting speed $[\mathrm{m} / \mathrm{s}]$ & Test & Stop path $[\mathrm{m}]$ & Deceleration $\left[\mathrm{m} / \mathrm{s}^{2}\right]$ & Stopping time [s] & Temp. $\left[{ }^{\circ} \mathrm{C}\right]$ \\
\hline \multirow{9}{*}{ S1 } & \multirow{9}{*}{27.7} & 1. & 47.52 & 7.8 & 3.52 & 67 \\
\hline & & 2. & 47.33 & 7.8 & 3.55 & 75 \\
\hline & & 3. & 48.00 & 7.6 & 3.60 & 82 \\
\hline & & 4. & 48.42 & 7.6 & 3.63 & 107 \\
\hline & & 5. & 48.05 & 7.6 & 3.60 & 140 \\
\hline & & 6. & 48.52 & 7.4 & 3.73 & 167 \\
\hline & & 7. & 48.96 & 7.2 & 3.84 & 213 \\
\hline & & 8. & 50.52 & 6.2 & 4.40 & 293 \\
\hline & & 9. & 52.51 & 5.9 & 4.62 & 327 \\
\hline \multirow{9}{*}{ S2 } & \multirow{9}{*}{27.7} & 1. & 48.55 & 7.5 & 3.69 & 85 \\
\hline & & 2. & 48.98 & 7.2 & 3.80 & 109 \\
\hline & & 3. & 49.85 & 7.0 & 3.95 & 124 \\
\hline & & 4. & 50.53 & 6.1 & 4.48 & 150 \\
\hline & & 5. & 51.83 & 5.5 & 4.95 & 193 \\
\hline & & 6. & 52.15 & 5.3 & 5.15 & 212 \\
\hline & & 7. & 52.88 & 4.7 & 5.85 & 344 \\
\hline & & 8. & 54.50 & 4.6 & 6.00 & 396 \\
\hline & & 9. & 55.15 & 4.0 & 6.88 & 464 \\
\hline \multirow{9}{*}{ S3 } & \multirow{9}{*}{27.7} & 1. & 48.50 & 7.0 & 3.95 & 79 \\
\hline & & 2. & 48.86 & 7.2 & 3.80 & 104 \\
\hline & & 3. & 49.05 & 6.9 & 3.96 & 119 \\
\hline & & 4. & 49.95 & 6.8 & 4.05 & 139 \\
\hline & & 5. & 50.45 & 6.2 & 4.45 & 163 \\
\hline & & 6. & 51.85 & 5.4 & 5.05 & 242 \\
\hline & & 7. & 52.32 & 5.0 & 5.51 & 299 \\
\hline & & 8. & 53.00 & 4.7 & 5.88 & 338 \\
\hline & & 9. & 54.15 & 4.5 & 6.06 & 402 \\
\hline
\end{tabular}

residues in the form of grooves caused by the abrasion of metal particles and fibres that first came into contact with the steel disk. The metal particles observed on the surfaces of the brake pads in Figure 7 disappeared after exploitation. These particles were

Table 4-Chemical composition of braking pads (wt\%) separated by the action of sliding and abrasion caused by contact with the steel disk at different sliding speeds and temperatures during operation.

Table 4 presents the results of the chemical analysis of all 3 samples.

\begin{tabular}{|c|c|c|c|c|c|c|c|c|c|}
\hline \multirow{2}{*}{ Braking pad } & \multicolumn{9}{|c|}{ Chemical composition [\%] } \\
\hline & $\mathrm{Fe}$ & $\mathrm{Al}$ & $\mathrm{Si}$ & $\mathrm{S}$ & $\mathrm{Ti}$ & V & $\mathrm{Cu}$ & $\mathrm{Zn}$ & \\
\hline S1 & 49.09 & 10.70 & 9.82 & 7.74 & 6.06 & 3.18 & 7.11 & 4.90 & \multirow{3}{*}{ Rest } \\
\hline S2 & 61.19 & 13.69 & 0.97 & 4.43 & 3.54 & 1.94 & 2.74 & 1.76 & \\
\hline $\mathrm{S} 3$ & 54.91 & 7.28 & 8.10 & 5.95 & 6.66 & 3.55 & 5.93 & 0.20 & \\
\hline
\end{tabular}



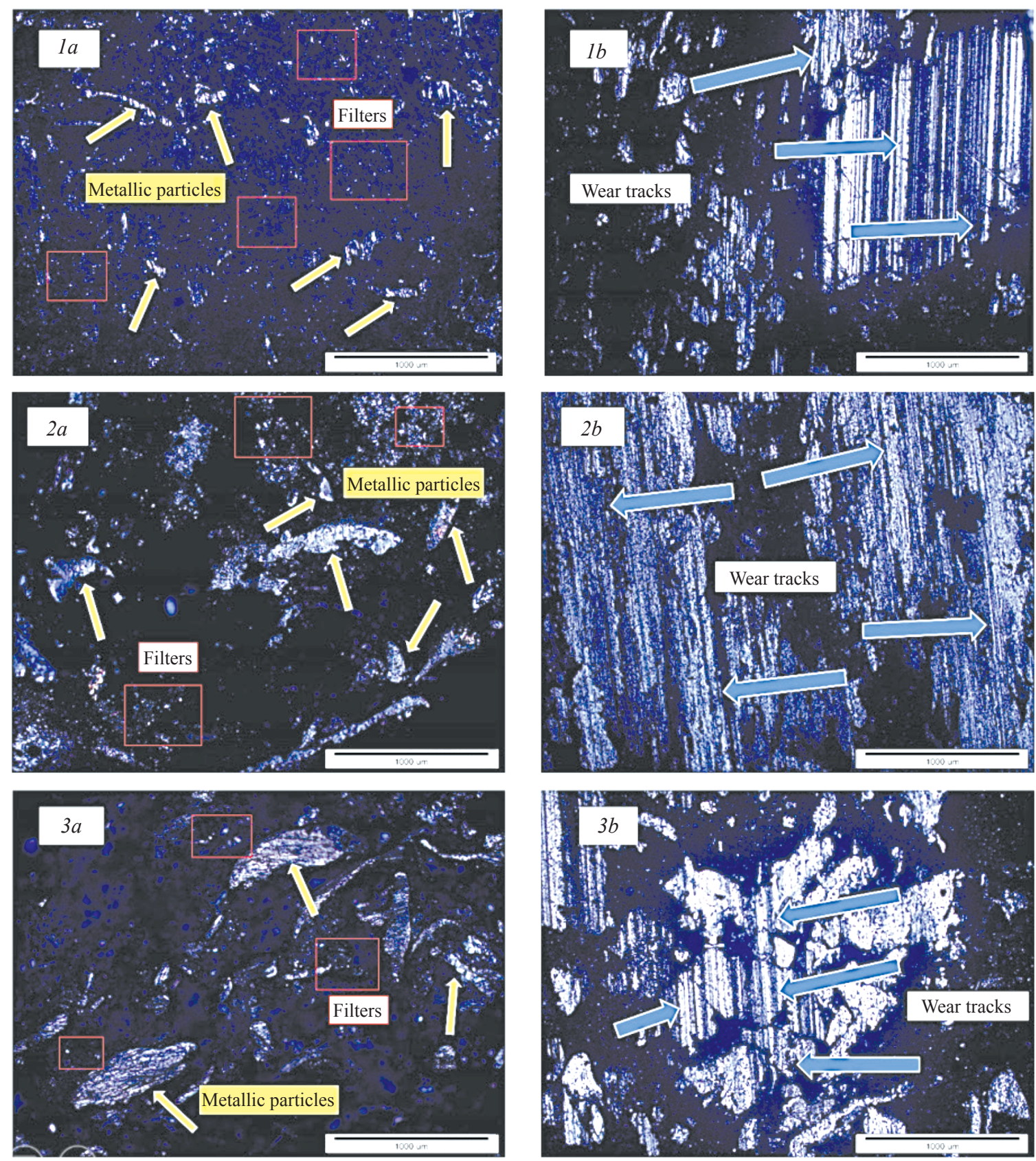

Figure 7 - Structure of brake pad surfaces before (a) and after (b) Sample $1(1 a, b)$, Sample $2(2 a, b)$ and Sample $3(3 a, b)$ tests

Elements found in pads such as $\mathrm{Mg}, \mathrm{Al}, \mathrm{Si}, \mathrm{S}$, and $\mathrm{Fe}$ are necessary additives to strengthen the substrate structures (binder, fillers, abrasives, and lubricants). Additionally, elements such as $\mathrm{Si}$ and $\mathrm{Al}$ can form metal oxides and carbides in combination with $\mathrm{C}$ and $\mathrm{O}$, such as alumina $\left(\mathrm{Al}_{2} \mathrm{O}_{3}\right)$ and silicon carbide ( $\mathrm{SiC}$ ), which are commonly used as ceramic fibres for high strength and high heat resistance to brake pads. An element such as Ti could be titanium carbide (TiC) used as an abrasive $[14,15]$.

The friction coefficient of all three specimens before and after the testing was measured by the block on ring method according to ASTM G77 $(n=5)$. Results are presented in Table 5 .

Table 5 - Mean friction coefficient before and after the testing

\begin{tabular}{||c|c|c|c||}
\hline Friction coefficient & S1 & S2 & S3 \\
\hline \hline Before & $0.428( \pm 0.006)$ & $0.401( \pm 0.007)$ & $0.393( \pm 0.006)$ \\
\hline After & $0.400( \pm 0.009)$ & $0.392( \pm 0.004)$ & $0.377( \pm 0.016)$ \\
\hline
\end{tabular}




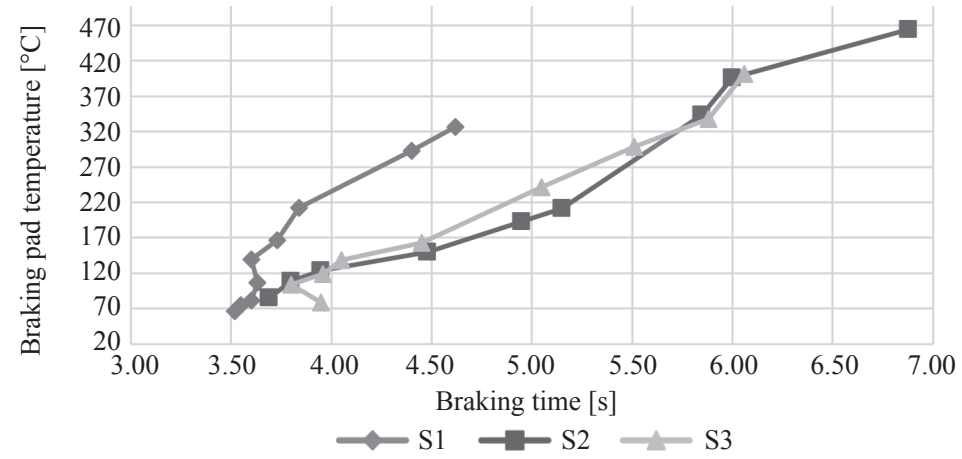

Figure 8 - Influence of brake pad temperature to braking time

Sample 1 was found to possess the highest friction coefficient before and after testing, while Sample 3 proved to be the worst.

The temperatures of the brake pads were measured by a portable pyrometer. Figure 8 shows the brake pad's temperature as a function of the stopping time.

It can be concluded that as the temperature increases, the stopping time of the car increases for all 3 samples, but sample 1 had a smaller elevated brake pad temperature effect on stopping time compared to samples 2 and 3, and especially sample 2 which proved to be the worst.

\section{CONCLUSION}

Based on the obtained results, the following can be concluded:

1) The most important factor for brake pads is the ratio of the elements Silicium $(\mathrm{Si})$ and Aluminium (Al) in the chemical composition because such elements provide the formation of carbides and oxides that are formed on the surface of the brake pads and enhance improvements of the braking characteristics. Chemical elements such as Titanium (Ti) could provide the formation of titanium carbide (TiC) which is also used as an abrasive.

2) The brake pads of Sample 1 have a high Si-Al ratio which can form, in combination with $\mathrm{C}$ and $\mathrm{O}$, metal oxides $\left(\mathrm{Al}_{2} \mathrm{O}_{3}\right)$ and carbides $(\mathrm{SiC})$ which have high hardness and wear resistance and form abrasive particles on the surface of the brake pads that contribute to improving performance in working conditions. Sample 1 also has a high share of $\mathrm{Ti}$ which further enhances the characteristics of brake pads and has the highest friction coefficient before and after the testing.
3) The brake pads with the highest price achieved the best results during field testing and also have a higher Si-Al ratio and a high share of Ti. They showed approximately $10 \%$ shorter stopping distance and approximately 30\% lower temperature during braking after the ninth intensive braking event than the brake pads of Sample 2 which have the worst $\mathrm{Si}-\mathrm{Al}$ ratio and $50 \%$ less Ti. The lowest temperature of the discs was recorded and there was no dangerously low deceleration. These brakes withstood the additional tests of stopping from the driving speed of 130 $\mathrm{km} / \mathrm{h}$ very well, with intensive braking of the car. The most expensive brakes have a smaller elevated brake pad temperature effect on stopping time compared to Samples 2 and 3. This is most likely due to the structure and composition of these brake pads which result in the highest friction factor compared to Samples 2 and 3.

4) Sample 2 presented the worst results (worst $\mathrm{Si}$ $\mathrm{Al}$ ratio and lower percentage of $\mathrm{Ti}$ ) in the tests, but it is the cheapest. The highest temperatures occurred during the test and during the last brake test, there was an ignition after which the brake pads were unusable and had to be changed.

5) All brake pads meet the requirements for use, but if they will be used in extreme conditions (e.g. freight or people transport) within the upper permissible load limit of the vehicle, it is recommended to install the most expensive brakes because they will continuously provide characteristics that contribute to traffic safety.

\section{ACKNOWLEDGMENT}

This work has been supported by Metal Centre Čakovec under the project KK.01.1.1.02.0023. All the equipment used for field testing was provided by the project KK.01.1.1.07.0013 Innovative Ti-Mg dental implants for the global market. 
Dalibor VIDERŠČAK, mag. ing. mech. ${ }^{1}$

E-mail: dalibor.viderscak@fsb.hr

prof. dr. sc. Zdravko SCHAUPERL

E-mail: zdravko.schauperl@fsb.hr

mr. sc. Krunoslav ORMUŽ ${ }^{1}$

E-mail: krunoslav.ormuz@fsb.hr

izv. prof. dr. sc. Sanja ŠOLIĆ ${ }^{2}$

E-mail:ssolic@unin.hr

izv. prof. dr. sc. Mladen NIKŠIĆ ${ }^{3}$

E-mail: mladen.niksic@fpz.unizg.hr

prof. dr. sc. Diana MILČIĆ

E-mail: diana.milcic@grf.hr

Pavao ORMUŽ mag. ing. mech. ${ }^{1}$

E-mail: pavao.ormuz@gmail.com

${ }^{1}$ Sveučilište u Zagrebu, Fakultet strojarstva i brodogradnje

Ivana Lučića 5, 10000 Zagreb, Hrvatska

${ }^{2}$ Sveučilište Sjever, Odjel za strojarstvo

J. Križanića 31b, 42000 Varaždin, Hrvatska

${ }^{3}$ Sveučilište u Zagrebu, Fakultet prometnih znanosti

Vukelićeva 4, 10000 Zagreb, Hrvatska

${ }^{4}$ Sveučilište u Zagrebu, Grafički fakultet

Getaldićeva 2, 10000 Zagreb, Hrvatska

\section{UTJECAJ SVOJSTAVA KOČIONIH OBLOGA NA KARAKTERISTIKE KOČENJA}

\section{SAŽETAK}

U ovom istraživanju provedena su terenska i laboratorijska ispitivanja tri komercijalno dostupni kočionih obloga s najnižom, srednjom i najvišom cijenom. Provedena su složena laboratorijska i terenska ispitivanja, gdje su kočione obloge testirane u stvarnim ekstremnim uvjetima na utovarenom kombiju. Terensko ispitivanje imalo je za cilj istražiti temperature koje se pojavljuju tijekom procesa kočenja te odrediti zaustavni put, usporavanje $i$ vrijeme zaustavljanja neovisno od vrste kočionih obloga. Laboratorijska ispitivanja uključivala su određivanje koeficijenta trenja prema ASTM G77, analizu strukture površina kočionih obloga prije i nakon ispitivanja te kvantitativnu kemijsku analizu. Cilj ovog istraživanja bio je utvrditi utjecaj temperature kočionih obloga na vrijeme kočenja ovisno o njihovim nabavnim cijenama. Dobiveni rezultati pokazuju značajnu razliku između temperature, koeficijenta trenja, kemijskog sastava $i$ vremena kočenja kočionih obloga i njihove cijene.

\section{KLJUČNE RIJEČI}

automobil; kočione obloge; zaustavni put; vrijeme zaustavljanja; koeficijent trenja; sastav; terenska ispitivanja.

\section{REFERENCES}

[1] Ormuž P. Characterization of brake lining material. Master thesis. University of Zagreb, Faculty of Mechanical Engineering and Naval Architecture; 2019.

[2] Balaji NSAC, Ramachandran B, Naga AG. Design and analysis of disk rotor brake under tribological behaviour of materials. Materials Today: Proceedings. 2020;33
(Part 7): 4298-4310. doi: 10.1016/j.matpr.2020.07.438.

[3] Nandhakumar S, Edwin SW, Shunmughanaathan VK. Experimental analysis of aluminium matrix composite material for braking application. Materials Today: Proceedings. 2021;37(Part 2): 2517-2520. doi: 10.1016/j. matpr.2020.08.375.

[4] Thendral SP, et al. Experimental investigation on the frictional wear behaviour of TiAlN coated brake pads. Materials Today: Proceedings. 2021;37(Part 2): 2419-2426. doi: 10.1016/j.matpr.2020.08.272.

[5] Seo $\mathrm{H}$, et al. Effect of disc material on particulate matter emissions during high-temperature braking. Tribology International. 2021;154: 106713. doi: 10.1016/j.triboint.2020.106713.

[6] Kumar S, Ghosh, SK. Porosity and tribological performance analysis on new developed metal matrix composite for brake pad materials. Journal of Manufacturing Processes. 2020;59: 186-204. doi: 10.1016/ j.jmapro.2020.09.053.

[7] Suxia Z, Zihao G, Bai X. Fatigue fracture analysis of brake disc bolts under continuous braking condition. Engineering Failure Analysis. 2020;115: 104588. doi: 10.1016/j. engfailanal.2020.104588.

[8] Ma X, et al. Comparison of braking behaviors between iron- and copper-based powder metallurgy brake pads that used for C/C-SiC disc. Tribology International. 2021;154: 106686. doi: 10.1016/j.triboint.2020.106686.

[9] Venkatesh S, Murugapoopathiraja K. Scoping review of brake friction material for automotive. Materials Today: Proceedings. 2019;16: 927-933. doi: 10.1016/j.matpr.2019.05.178.

[10] Day A. Braking of Road Vehicles. Butterworth-Heinemann; 2014. p. 35-65. doi: 10.1016/b978-0-12-3973146.00003-6.

[11] Rashid A. Overview of disc brakes and related phenomena - A review. International Journal of Vehicle Noise and Vibration. 2014;10(4): 257. doi:10.1504/ijvnv.2014.065634.

[12] Shiva SP. A review on properties of conventional and metal matrix composite materials in manufacturing of disc brake. Materials Today: Proceedings. 2018;5(2): 5864 5869. doi: 10.1016/j.matpr.2017.12.184.

[13] Hatam A, Khalkhali A. Simulation and sensitivity analysis of wear on the automotive brake pad. Simulation Modelling Practice and Theory. 2018;84: 106-123. doi: 10.1016/j.simpat.2018.01.009.

[14] Arman M, Singhal S, Chopra P, Sarkar M. A review on material and wear analysis of automotive break pad. Materials Today: Proceedings. 2018;5(14): 28305-28312. doi: 10.1016/j.matpr.2018.10.114.

[15] Laguna-Camacho JR, et al. A study of the wear mechanisms of disk and shoe brake pads. Engineering Failure Analysis. 2015;56: 348-359. doi: 10.1016/j.engfailanal.2015.01.004.

[16] Xiao X, et al. Review on the friction and wear of brake materials. Advances in Mechanical Engineering. 2016;8(5). doi: 10.1177/1687814016647300.

[17] Chandra VP, et al. Braking pad-disc system: Wear mechanisms and formation of wear fragments. Wear. 2015;322323: 251-258. doi: 10.1016/j.wear.2014.11.019.

[18] Zhang P, et al. Effect of carbon fiber on the braking 
performance of copper-based brake pad under continuous high-energy braking conditions. Wear. 2020;458-459: 203408. doi: 10.1016/j.wear.2020.203408

[19] Jadhav SP, Sawant SH. A review paper: Development of novel friction material for vehicle brake pad application to minimize environmental and health issues. Materials Today: Proceedings. 2019;19(Part 2): 209-212. doi: 10.1016/j.matpr.2019.06.703

[20] Nagesh SN, Siddaraju C, Prakash SV, Ramesh MR. Characterization of brake pads by variation in composition of friction materials. Procedia Materials Science.
2014;5: 295-302. doi: 10.1016/j.mspro.2014.07.270.

[21] Sallit I, Richard C, Adam R, Robbe-Valloire F. Characterization methodology of a tribological couple. Materials Characterization. 1998;40(3): 169-188. doi: 10.1016/ s1044-5803(98)00007-2.

[22] Matijević B, Grilec K, Rede V, Haramina T. Materials 2, Exercise mats. Zagreb, Croatia: University of Zagreb, Faculty of Mechanical Engineering and Naval Architecture; 2020. https://www.fsb.unizg.hr/usb_frontend/files/1614613017-0-materijali2_podloge_za_vjezbe 2020 21.pdf [Accessed 3th May 2021]. 